\title{
Improving Students' Skill in Writing Recount Text Using Pictures
}

\author{
Retno Nurlita, Martono, Ngadiso \\ English Education Department \\ Teacher Training and Education Faculty \\ Sebelas Maret University of Surakarta \\ Email: nurlitaretno@yahoo.co.id
}

\begin{abstract}
This article discusses the result of an action research which is aimed at improving students' skill in writing recount text using pictures. The objectives of the research are (1) to find out whether the use of picture can improve students' skill in writing recount texts; (2) to describe the students' itensity while picture is applied in writing class; and (3) to investigate the advantages and disadvantages of the use of pictures to improve students' skill in writing recount text. This research was carried out at one state junior high school in Sokaraja. The method used in this research was classroom action research. To collect the qualiatative data, the researcher used questionaire, observation, interview, and photograph. In collecting the quantitative data, the researcher used pre-test and post-test. The research was conducted in two cycles, in which the first cycle consists of three cycles and the second cycles consists of three cycles. Both the qualitative and quantitaive data were analyzed to answer the problem statement above. Qualitative data were analyzed by using 5 steps suggested by Burns (1999:157160) as follows: assembling the data, coding the data, comparing the data, building interpretation, and reporting the outcomes. Meanwhile, the quantitative data were analyzed using descriptive statistics. In counting the students' test score, the researcher used the writing scoring rubric for evaluating recount writing. The result of the research shows that: (1) the use of pictures can improve students' skill in writing recount texts, (2) the improvements of the students' intensity while picture is applied are the students had high motivation to join the teaching and learning process and they had good spirit to learn English while the picture is applied in writing class, and (3) advantages and disadvantages of pictures to improve students' skill in writing recount text, for example: pictures gives more interest and motivation to the students in teaching and learning process and gives them stimulus about certain topic to brainstorm the students so that they can write with detail information as what is presented in the picture.
\end{abstract}

Key words: pictures, writing, classroom action research

\section{INTRODUCTION}

Writing is usually directed to others for a specific purpose. Students usually learn to write in school. The first is writing words, then isolated sentences, and later a paragraph. Writing is the activity or occupation of writing, for example books, stories or articles. We can take more times to think and choose words in order to express our idea, thought, and feeling. In addition, Finnochiaro (1974: 86) says that writing has been characterized as written thinking. It means that writing is a way to produce language that comes from our thought. In the writing process, the writer tries to develop their ideas and feelings to 
produce into a good sentence in order to inform the other.

Based on Kurikulum Tingkat Satuan Pendidikan 2006, learning writing in Junior High School is aimed at making the students able to express idea in the written from by using appropriate language variation fluently and accurately in short functional text and monologue in the form of procedure, descriptive, recount, narrative, report, and public speaking. For especially the eighth grade, it is limited on descriptive, recount, and narrative texts. The students should express and develop the topic of the text, organize the paragraph in a text, use appropriate vocabulary, construct sentences, and use convention in writing. Every students gets score is 70 for KKM in English language learning.

After the researcher interviewed the teacher, researcher conducted the preobservation and interviewed the students. Every students had difficulty in writing lessons, such as: (1) the students had difficulty to explore their ideas, (2) the students had problems in producing grammartically correct sentences, (3) the students had problems to use proper word in writing, (4) the students had difficulty in organizing ideas, and (5) the students had difficulty to use mechanics (spelling, capitalization, and punctuation).

The problem faced by students are caused by some factors that come from the teacher, students, and teaching and learning process. First, the causes from the teacher are: she did not give a model of writing to write a sentence or paragraph that made the students know what to do for writing, teacher did not give outline to his/her students to guide them in writing a sentence or paragraph, and teacher's method makes them lazy and bored. Second, the causes from students are: during the writing lesson time, the students did not bring the dictionary so that they did not write well in the beginning. They prefer writing assignment as their homework than finishing it in classroom. Those indicate that they have low motivation in writing. Low motivation causes the students not to develop their ability in writing. The last, the causes from the teaching and learning process are: there is not any media in teaching learning process to support or guide the students in writing and they need the new situation, new atmosphere and new method to make them feel excited, comfortable, and satisfied to learn English.

From the problems and causes above, choosing suitable media is one of important aspects. There are many media that can help the students write easily and correctly. One of the media is picture. Webster (1979: 1357) defines that pictures are an image or likeness of an object, person, scene reproduced on a flat surface, especially by painting or photograph, a mental image or impression, an idea. In addition, Hill (1990: 1) states pictures did not only bring images of reality, but can also function as a fun element in the class. Sometimes it is surprising, how pictures may change a lesson, even if only employed in additional exercises or just to create the atmosphere.

Picture is chosen because it has many advantages. Picture can be applied in teaching writing. Secondly, it can be applied in some genres, such as descriptive, recount, and narrative. Thirdly, picture provides clear object that is useful to help students to understand the language items that are given to them. Fourthly, picture gives more interest and motivation in learning because students will be attracted to the object in the 
picture and also the color in the picture. And the last, the direction for writing in picture media is made as clearly as possible so that the students will not be confused.

The development of each indicator is as follows: First, using pictures in exploring their ideas to help the students to explore their ideas, because the word that is related to the pictures shows them what they have (words) to make a text. It means that this development can guide the students to list the content and also develop the topic of the text. Second, the development of grammar is that pictures are used to give context either to presentation of grammar or do the exercises and grammar presentation. For example: students did exercises and made a story based on the pictures. Third, the development of vocabulary is that pictures are used to help the students choose the word that was suitable with the context in the topic based on the picture. Fourth, the development of organizing ideas is that pictures are used to help the students organize their ideas logically. The last, development of mechanics is pictures are used to guide the students to use correct writing's convention suh as punctuation, spelling, and capitalization.

A classroom action research was used in the research. Purposes of research are: to solve the problems of students' skill in writing recount text in the eighth grade students of SMP Negeri 2 Sokaraja and uses the picture as media to teach writing.

\section{RESEARCH METHOD}

This research was conducted at one of state junior high school in Sokaraja, including doing pre-research and pre-test, implementing the action, and doing posttests. This study was conducted to the eighth grade students of Junior High School. It consists of 32 students including 18 girls and 14 boys. The method used in this research is action research. Kemmis (1983) in Hopkins (1993:4) says that action research is a form of self- reflective inquiry undertaken by participants in social (including educational) situation in order to improve the rationality and justice of a (a) their own social or educational practices; (b) their understanding to these practices; and (c) the situations in which the practices are carried out.

Furthermore, Kemmis and McTaggart (1988) in Burns (1999:23) who state the action research occurs through a dynamic and complementary process which consists of four fundamental steps in a spiraling process. They are as follows: (1) planning, (2) action, (3) observation, and (4) reflection.

There are two kinds of techniques of collecting data in this research, such as: qualitative data and qualitative data. Qualitative data were taken from result of observation, interview, field notes, and photographs. Meanwhile, quantitative data were taken from the result of the test, including the students' scores of pre-test and post-test.

Further, the data were analyzed by qualitative and quantitative methods. The qualitative method was used to analyze the data taken during the teaching learning process. There are some processes of analyzing qualitative data in action research. Burns (1999, 157-160) mentions the following processes: (1) assembling the data; (2) coding the data; (3) comparing the data; (4) building interpretation; reporting the outcome. 
To analyze the quantitative data, the researcher used descriptive statistics. To measure the students' score, the scoring rubric is taken from Genesse and Upshur (1996: 206). The range of scores is from one to thirty. It is adapted to evaluate students' writing. The students are tested on five indicators, they are: content, organization, vocabulary, grammar, and mechanics (punctuation, spelling, and capitalization).

\section{RESEARCH FINDINGS AND DISCUSSIONS}

Before doing the action, there is a step called pre-research. In this step, the researcher observed the teaching learning process, interviewed the teacher and several students, distributed questionnaire to the 32 students and conducted pre-test. Considering the results of pre-research, the researcher identified the problems in writing that were faced by the students are caused by some factors that come from the teacher, the students, and teaching learning process. First, the causes from the teacher are: she did not give a model of writing to write a sentence or paragraph that made the students know what to do for writing, teacher did not give outline to his/her students to guide them in writing a sentence or paragraph, and teacher's method made them lazy and bored. Second, the causes from students are: during the writing lesson time, the students did not bring the dictionary so that they did not write well in the beginning. They prefered writing assignment as their homework than finishing it in classroom. Those indicate that they have low motivation in writing. Low motivation causes the students not to develop their ability in writing. The last, the causes from the teaching and learning process are: there is not any media in teaching learning process to support or guide the students in writing and they need the new situation, new atmosphere and new method to make them feel excited, comfortable, and satisfied to learn English. To overcome those problems, the researcher proposed to improve students' skill in writing recount text using pictures. The research was conducted in two cycles. There were three meetings in the first cycle and three meetings in the second cycle. After each cycle was done, the researcher conducted post-test to identify the improvement of students' skill in writing.

The research findings proved that the students' skill in writing and class situation were succesfully improved by implementing picture. The improvement of students' skill in writing recount texts could be identified from the students' mean score of each writing aspect from Pre-test, Post-test 1, and Post-test 2 . It can be seen from table 1 until table 3.

Table 1 Mean score of each writing aspect in pre-test

\begin{tabular}{|c|c|c|c|c|c|}
\hline \multirow[b]{2}{*}{ No. } & \multirow[b]{2}{*}{ Aspects } & \multicolumn{4}{|c|}{ Score } \\
\hline & & $\begin{array}{c}\text { Corrector } \\
1\end{array}$ & $\begin{array}{c}\text { Corrector } \\
2\end{array}$ & $\begin{array}{l}\text { Inter- } \\
\text { rater } \\
\text { Score }\end{array}$ & $(\%)$ \\
\hline 1 & Content & 18.47 & 18.66 & 18.56 & 61.9 \\
\hline 2 & Organization & 16.3 & 15.9 & 16.1 & 80.47 \\
\hline 3 & Vocabulary & 15.7 & 15.9 & 15.77 & 78.83 \\
\hline 4 & Language Use & 15.3 & 14.56 & 14.94 & 59.75 \\
\hline 5 & Mechanics & 3.28 & 3.28 & 3.28 & 65.63 \\
\hline & Total Score & 69.1 & 68.3 & 68.64 & 69.31 \\
\hline
\end{tabular}


Table 2. The Students' Mean Score in Cycle 1

\begin{tabular}{|c|c|c|c|c|c|}
\hline \multirow{3}{*}{ No. } & \multirow{3}{*}{ Aspects } & \multicolumn{4}{|c|}{ Score } \\
\hline & & \multirow[b]{2}{*}{ Corector 1} & \multicolumn{3}{|c|}{ Inter- rater } \\
\hline & & & Corector 2 & Score & $(\%)$ \\
\hline 1 & Content & 20.16 & 21.75 & 20.47 & 68.23 \\
\hline 2 & Organization & 16.1 & 15.94 & 16.14 & 80.70 \\
\hline 3 & Vocabulary & 16.5 & 16.41 & 16.31 & 81.56 \\
\hline 4 & Language Use & 16.56 & 18.1 & 16.44 & 65.75 \\
\hline 5 & Mechanics & 3.66 & 3.94 & 3.66 & 73.13 \\
\hline & Total Score & 73.14 & 72.98 & 73.02 & 73.87 \\
\hline
\end{tabular}

Table 4.3 The Students' Mean Score in Cycle 2

\begin{tabular}{cccccc}
\hline \multirow{2}{*}{ No. } & \multirow{2}{*}{ Aspects } & \multicolumn{5}{c}{ Score } \\
\cline { 2 - 6 } & & Corrector 1 & Corrector 2 & Inter- rater Score & $(\%)$ \\
\hline 1 & $\mathrm{C}$ & 21.75 & 21.3 & 21.55 & 71.82 \\
2 & $\mathrm{O}$ & 15.94 & 16.1 & 16.02 & 80.1 \\
3 & $\mathrm{~V}$ & 16.41 & 16.19 & 16.30 & 81.48 \\
4 & $\mathrm{~L}$ & 18.1 & 18.2 & 18.17 & 72.69 \\
5 & $\mathrm{M}$ & 3.94 & 3.94 & 3.94 & 78.75 \\
\hline \multicolumn{2}{l}{ Total Score } & 76.14 & 75.73 & 75.97 & 76.96 \\
\hline \multicolumn{2}{r}{} & & from 78.83 (pre-test),
\end{tabular}

The improvements of the students' skill in writing recount texts in this research involved five indicators, those are: content, organization, vocabulary, language use, and mechanics. Picture is as media to teach writing in junior high school especially on eight grade students so that it can improve the students' skill in writing recount texts.

a. The use of picture improves students' skill in exploring the ideas.

Using picture in the writing class, the students' skill in exploring the ideas improved. The students were able to explore their ideas to write and more relevant to the topic. The mean score of content improved from 61.9 (pre-test), 68.23 (post-test 1),71.82 (post-test 2).

b. The use of picture improves students' skill in vocabulary.

Using picture in the writing class, the students' skill in vocabulary improved. They began to be able to choose appropiate words for their writing. The mean score of vocabulary improved

81.56 (post-test 1), and 81.48 (post-test 2).

c. The use of picture improves students' skill in organization.

Using picture in the writing class, the students' skill in organization improved. The students were more fluent in expressing the idea and their writing was logical. The mean score of organization improved from 80.47 (pre-test), 80.70 (post-test 1), and 80.1(post-test 2).

d. The use of picture improves students' skill in language use.

Using picture in the writing class, the students' skill in language use improved. The students made better sentences and used simple past tense, noun phrase, conjunction, and adverb in a better way. The mean score of language use improved from 59.75 (pre-test), 65.75(post-test), 72.69 (post-test 2). 
e. The use of picture improves students' skill in mechanics.

Using picture in the writing class, the students' skill in mechanics had improved. The students' writing was better organized in paragraphing and also much better in spelling, punctuation, and capitalization. It also shown by the improvement of mechanic score in pre-test (65.63), post test 1 (73.13), post-test 2 (78.75).

The second improvement was the students' intensity while pictures were applied in writing class. Using picture in the writing class, the students' intensity improved. They were motivated by using pictures. There are some itensities, they are: enthusiasm, and passion. The improvements of intensities are: the students had high motivation to join the teaching and learning process and they had good spirit to learn English while the picture was applied in writing class.

a. The students paid attention to the teacher The students showed positive attitude towards writing lesson. The students were more active during the teaching and learning process. Most of them paid attention and participated in all activities. They were able be express the ideas in their story.

b. The students had high motivation and interest to join the teaching and learning process.

The students' attitude towards writing had changed to be better. It was not hard to ask them to write a story. They were also interested and motivated to join and to get involved in teaching and learning process.

c. The students became more active in teaching and learning process

The students showed positive attitudes towards writing lesson. The students became more active and enthusiastic both in responding the researcher and finishing the exercises given. They asked questions to the teacher and also answered the teacher's question.

The third there are advantages and disadvantages of picture to improve students' skill in writing recount text. The advantages of the picture in the teaching learning process of writing skill after the action research showed that the students were motivated and confident when they were asked to write in groups and individually by seeing the picture first. They did their writing without being asked many times and did not complain anymore. By seeing the pictures, the students could spend shorter time when they were asked to write and most of the students could finish their writing on time. It is because the pictures could help them by presenting certain topic which can be written down. Some students discussed actively about the topic in the pictures in their own group after they saw the pictures.

Their motivation can be seen from their activity during the action, they paid close attention when the researcher showed the pictures, they felt comfortable and did not look bored. It would be easier for students to write the story based on the picture because they still remembered what they saw. This finding is supported by Wright (1997:10). Picture plays a key role in motivating students, conceptualizing the language they want to use, giving them a reference, and helping to discipline the activity.

The disadvantages of picture to teach writing are students pay attention to the picture more than learning about the material, the process of teaching and learning using picture takes more time to 
provide attractive pictures, and small and unclear pictures become problems in teaching learning process since the students misunderstand about pictures. This finding is supported by Zenger (1991:79). Every teacher wants to choose pictures that are fascinating to their students. In order to choose the right pictures to suit our students' interest, we takes more time and we have to understand first. We should take into consideration their age and their attitude as well. Some images are small in size while some are high in resolution and pleasing to the eyes. Choosing the right images will depend on how big and clear you want them to be. The colour of picture should also be considered while choosing an image.

\section{CONCLUSIONS AND SUGGESTIONS}

There are three conclusions based on the research findings and discussion. The first is about the improvement of pictures towards the students' skill in writing recount text. It could be proved from the results of the students' tests which had improvement of mean score in every cycle. In the pre-test the students obtained 69.31 , in the post-test 1 the mean score increase become 73.87 and in the post-test 2 the mean score increase up to 76.96. The students' skill in writing increased in all aspects. The students could apply the appropriate tense in their writing. In this action researcher gave enough opportunity to write, the teaching learning focused more on writing skill. Through this action, the students could have more practices in writing recount texts using pictures. They could create a better writing than before including in constructing the past sentences by using simple past tense. The students could also change the verb 1 into verb 2 in correct forms. It could be seen in the students' worksheets in which the mistakes were fewer than before. The results of the test also support the positive improvements.

The second is the students' intensity while the picture is applied to improve students' skill in writing improved. The improvements of intensities are: the students had high motivation to join the teaching and learning process and they had good spirit to learn English while the picture media is applied in writing class.

The third is there are also some advantages and disadvantages of teaching and learning process when the picture was used in teaching recount texts. The students were more motivated in writing while the pictures were used as a teaching media. Their motivation could be seen from their activity during the action, they paid attention when the researcher showed the pictures, they felt comfortable and they did not look bored. It would be easier for the students to write the story on the paper because they still remembered what they saw while the teacher showed the pictures. The disadvantages of picture to teach writing are students paid attention on the picture more than learning about the material, the process of teaching and learning using picture took more time to provide attractive picture, small and unclear pictures became problems in teaching learning process since the students misunderstand about pictures.

In achieving the objectives of teaching and learning process, it is really important to apply suitable media. The appropriate choice will contribute good impact in both process and result of the teaching and learning itself. According to the research findings, picture is one of effective media to improve students' skill in writing recount texts. 
Considering the findings of this research, there are some suggestions offered. For the teachers, it is recomended for them to create interesting activities and enjoyable situation in teaching learning process in class. They should be creative in selecting media to teach writing. Teaching writing using picture can be a good choice as media which can be implemented in the writing class.

For the students, they should have high motivation from themselves when they want to learn writing, active in English class and practice writing frequently.

For other researchers, the result of this study can be used as additional reference for further research in other language skills in order to create a better teaching learning process. They should also do the research further to find out the weakness which still happened.

\section{BIBLIOHRAPHY}

Burns, Anne. (1999). Collaborative Action Research for English Language Teachers. Cambridge: Cambridge University Press
Finnochiaro,Marry. (1974). English as Second Language :from Theory to Practice. New York: Regents Publishing Company, Inc

Genesse, Freed and Upshur John A.(1996). Classroom Based Evaluation in Second Language Education. New York: Cambridge University Press.

Hill, David A. (1990). Visual Impact: Creative Language Learning Through Picture. Essex: Longman Group UK Limited.

Hopkins, David. (1993). A Teacher's Guide Classroom Research. Great Britain: St Edmundsbury Press Ltd

Noah, Webster. (1994). Webster New World Dictionary of American English. Prantice Hall. 